DOI 10.23859/2587-8344-2018-2-3-3

УДК 94

\author{
Петелин Борис Валентинович \\ Доктор исторических наук, профессор \\ Череповецкий государственный университет \\ (Череповец, Россия) \\ pbwtscherepowez@mail.ru \\ Petelin Boris \\ Doctor of Historical Sciences, Professor \\ Cherepovets State University \\ (Cherepovets, Russia) \\ pbwtscherepowez@mail.ru
}

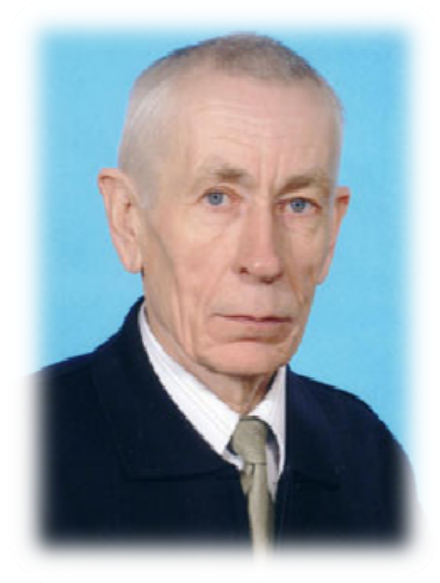

\title{
Профессор В.Б. Конасов: между российской и германской историей"
}

\section{Professor V.B. Konasov: Between Russian and German History}

Аннотащия. Имя вологодского историка, доктора исторических наук, профессора Виктора Борисовича Конасова известно не только в России, но и в Германии. Занимаясь историей военного плена, он на широкой документальной основе из засекреченных ранее документов отразил в своих книгах, статьях и выступлениях судьбы немецких военнопленных в СССР. Были показаны политические, правовые, социальные факторы и условия советского плена, отличавшегося куда большей гуманностью, чем немецкий плен для миллионов советских солдат и офицеров. Научная, педагогическая, общественная деятельность В.Б. Конасова, как отмечается в данной статье, давно получила заслуженное признание среди российского исторического сообщества, а его дела, начинания и поиски продолжают его ученики.

Ключевые слова: военный плен, российская истории, послевоенная Германия, историкигерманисты, международное право, пенитенциарная система, историческая память.

* Для цитирования: Петелин Б.В. Профессор В.Б. Конасов: между российской и германской историей // Historia Provinciae - Журнал региональной истории. 2018. Т. 2. № 3. С. 145172. DOI: $10.23859 / 2587-8344-2018-2-3-3$

For citation: Petelin, B.V. "Professor V.B. Konasov: Between Russian and German History". Historia provinciae - The journal of regional history, vol. 2, no. 3 (2018): 145-72, https:// doi.org/ $10.23859 / 2587-8344-2018-2-3-3$

(C) Петелин Б.В., 2018

(C) Petelin B., 2018 
Abstract. The name of the Vologda historian, doctor of historical sciences, professor Viktor Borisovich Konasov is known not only in Russia, but also in Germany. Dealing with the history of military captivity, he reflected in his books, articles and speeches upon the fates of German prisoners of war in the USSR on a broad documentary basis originating from previously classified records. Certain political, legal and social factors were shown, as well as the conditions of Soviet captivity, which was much more humane than German captivity for millions of Soviet soldiers and officers. V.B.Konasov's scientific, pedagogical and social activities, as noted in this article, have received a well-deserved recognition among the Russian historical community, and his students continue his work, endeavours and studies.

Keywords: military captivity, history of Russia, post-war Germany, historians-Germanists, international law, penitentiary system, historical memory

\section{Введение}

В 2010 г. в Вологде был издан научный сборник «Историк и его время», посвященный памяти доктора исторических наук, профессора Виктора Борисовича Конасова, фактически к его 60-летию, до которого он не дожил двух лет 1 . Издание получилось фундаментальным, с широким охватом исторических тем и проблем, как по отечественной, так и зарубежной истории. Финансовую поддержку оказал Санкт-Петербургский филиал Фонда им. Конрада Аденауэра, что как нельзя лучше иллюстрирует название нашей статьи. Сборник вызвал интерес среди читателей, по-прежнему пользуется устойчивым спросом у специалистов-исследователей. Все, обратившиеся к его содержанию, непременно прочтут материалы о самом Викторе Борисовиче, его жизненном пути, педагогической и научной деятельности.

\section{Основная часть}

Мне, близко знавшему Виктора Конасова, его обращение к проблеме военного плена - пребыванию немецких солдат и офицеров в советском плену представляется естественным и закономерным, учитывая его нацеленность на творческий поиск в исследовании новых тем в истории Второй мировой войны $^{2}$. Настоящий ученый должен обладать неким «историческим чутьем» (иногда это именуют «конъюнктурным подходом»), отвечать на запросы времени. После распада СССР, в силу начавшегося пересмотра многих событий в отечественной истории, расширился доступ к ранее засекреченным документам. Это «окно» вскоре захлопнулось, но для инициативных исследователей, таких, как

${ }^{1}$ См.: Историк и его время. Памяти профессора В.Б. Конасова: сборник статей. Вологда: Граффити, 2010.

2 Петелин Б.В. Профессор В.Б. Конасов и проблемы изучения и преподавания истории Второй мировой войны в контексте современности // Историк и его время. Памяти профессора В.Б. Конасова: сборник статей. Вологда: Граффити, 2010. С. 14-23. 
Виктор Конасов, этой возможности вполне хватило. Автор рассказывал мне, что когда он осенью 1991 г. начал работать в Российском государственном военном архиве (в то время - Особый архив), большинство документов, на которых стоял гриф «секретно», или «сов. секретно», никто до него не читал. Лишь некоторые попадали ранее в руки одного-двух человек. Так, он называл генерал-лейтенанта Д.А. Волкогонова, который в 1990-е гг. был членом Комиссии по рассекречиванию документов и одновременно председателем Комиссии при Президенте Российской Федерации по военнопленным, интернированным и пропавшим без вести. Такой же плодотворной была работа Виктора Конасова в Архиве внешней политики Российской Федерации. Собранные материалы (а работа оказалась необычайно сложной и трудной) легли в основу его самой известной и популярной книги «Судьбы немецких военнопленных в СССР...»³.

О книге мы еще скажем. Путь к ней не был прямым, но и извилистым его не назовешь. Интерес к военной тематике Виктор Конасов проявил еще в студенческие годы, когда начал собирать письма и воспоминания вологжанфронтовиков. После окончания истфака ВГПИ работал в городских образовательных учреждениях, а с 1987 г. вплотную занялся подготовкой кандидатской диссертации, посвященной деятельности военно-санитарной службы Красной Армии в годы Великой Отечественной войны. В 1990 г. диссертация была успешно защищена. Некоторое время мы с ним работали на одной кафедре в Вологодском молочном институте, а в дальнейшем встречались уже в стенах Вологодского государственного педагогического университета. В 1991 г. Виктор Конасов подготовил и издал небольшую брошюру «Гриф секретности снят», в которой был поднят вопрос о немецких военнопленных в $\mathrm{CCCP}^{4}$. Именно с нее, можно сказать, кандидат исторических наук В.Б. Конасов стал заниматься германской историей, пусть и проходившей в годы войны на советской территории.

С одной стороны, раз речь идет о немцах, то это тема для историковгерманистов, тех, кто изучает у нас историю Германии. Но с другой - плен все же «советский» и все, что было связано с ним, определялось советскими органами, законами, приказами, распоряжениями. В этом заключалась главная сложность исследования... Впоследствии Виктору Борисовичу не раз задавали вопрос: «На кого работаешь? На Германию или Россию?» В упомянутой брошюре автор упрекает сталинское руководство за то, что СССР не присоединил-

${ }^{3}$ Конасов В.Б. Судьбы немецких военнопленных в СССР: дипломатические, правовые и политические аспекты проблемы. Очерки и документы. Вологда: Вологодский институт повышения квалификации и переподготовки педагогических кадров, 1996.

${ }^{4}$ Конасов В.Б. Гриф секретности снят: (к истории немецких военнопленных в СССР). Вологодский государственный педагогический институт, Группа «Поиск». Вологда: Вологодский государственный педагогический институт, 1991. 
ся к Женевским конвенциям об обращении с военнопленными и об улучшении участи раненых и больных в действующих армиях. Это, якобы, развязывало руки гитлеровцам в отношении советских военнопленных. Слабый аргумент! Подписал бы Советский Союз конвенции 1929 г., не подписал - участь красноармейцев, попавших к немцам в плен, осталась бы без изменений. Некорректными выглядели суждения автора о «чрезмерной жестокости» в обращении с немецкими военнопленными. Только один пример: по утвержденным нормам 1941 г. им ежедневно было положено 700 грамм хлеба, дополнительно еще другие продукты, которые исчезли для советских граждан в годы войны. Да, СССР не ставил подписи под Женевскими конвенциями 1929 г., но не уклонялся от их соблюдения (1 июля 1941 г. советское правительство приняло «Положение о военнопленных», не противоречившее в целом нормам международного гуманитарного права).

Вернемся к книге «Судьбы немецких военнопленных в СССР...». Она действительно вызвала немалый интерес. Отклики и рецензии появились в разных изданиях. Я тоже откликнулся, опубликовав небольшой материал в вологодской газете «Русский Север» ${ }^{5}$. Не пересказывая содержание книги об участи немецких военнопленных, я отметил, что «советский плен был более гуманным», что было видно из помещенных в книге документов. Меня, как историкагерманиста, больше привлекло описание возвращения немцев к себе на родину, о чем рассказал автор во второй главе своей книги ${ }^{6}$. Возвращать военнопленных стали практически сразу после капитуляции фашистской Германии. В первую очередь раненых, больных, нетрудоспособных, что казалось вполне гуманным, но, на самом деле, вернувшиеся на родину столкнулись с такими проблемами, что многие из них кончали жизнь самоубийством ${ }^{7}$.

Последняя страница в истории «советского плена» была перевернута в сентябре 1955 г., во время официального визита канцлера ФРГ Конрада Аденауэра в Москву. Работа в архивах помогла Виктору Борисовичу назвать реальную цифру бывших немецких военнопленных, находившихся в лагерях СССР на тот момент - 9626 «задерживаемых лиц». Аденауэр связывал установление дипломатических отношений с СССР с освобождением всех «удерживаемых немцев», при этом называлось их количество - не менее 130 тыс., правда без какихлибо списков. По словам канцлера, невыносима сама по себе мысль, что спустя 10 лет после окончания войны, люди, втянутые в водоворот военных событий,

5 «Русский Север». 1996. 7 мая.

${ }^{6}$ Конасов В.Б. Судьбы немецких военнопленных в СССР... Вологда, 1996. С. 123-174.

${ }^{7}$ См.: Образцова E.B. Ресоциализация немецких военнопленных после возвращения из СССР (1945-1955): автореф. дис. ... канд. истор. наук. Воронеж, 2017. На с. 4-5 автор особо выделяет исследования В.Б. Конасова, который смог всесторонне проанализировать судьбы немецких военнопленных.

${ }^{8}$ Конасов В.Б. Судьбы немецких военнопленных в СССР... Вологда, 1996. С. 173. 
«задерживаются до сих пор вдали от своих семей, от своей родины, от своего нормального мирного труда» ${ }^{9}$. Следует сказать, что Конрад Аденауэр озвучил тогда позицию своей партии - ХДС, председателем которой он являлся ${ }^{10}$.

Вернувшиеся из затянувшегося плена немцы действительно «благодарили» Аденауэра, хотя решение об их освобождении было принято в СССР еще до визита канцлера. Сам Аденауэр на заседании правления ХДС 30 сентября 1955 г. весьма подробно рассказал о своем визите в Москву, о своих впечатлениях от переговоров с советскими руководителями, не забыв охарактеризовать каждого из них, о Москве, москвичах. Враждебности в его словах не было. Канцлер был доволен: почти половина опрошенных немцев (48\%) одобрили переговоры в Кремле и лишь $9 \%$ посчитали их «провалившимися» ${ }^{11}$. В 1956 г. смогли выехать из СССР последние военнопленные - 749 человек, которых «на родине не сочли возможным снова помещать в тюремные камеры...» ${ }^{12}$.

Еще до выхода книги В.Б. Конасова проблема военного плена стала одной из главных на международной конференции, посвященной 50-летию создания Национального комитета «Свободная Германия». Конференция проходила в Красногорске, под Москвой, в здании Мемориального музея немецких антифашистов (в 1943 г. здесь находилась «Центральная школа антифашистов»), ставшего в 2005 г. филиалом Центрального музея Великой Отечественной войны 1941-1945 гг. Среди участников конференции, известных российских и немецких историков, были и бывшие военнопленные, входившие в состав НКСГ и СНО (Союз немецких офицеров). Пожалуй, самой колоритной фигурой на конференции был граф Генрих фон Айнзидель, внучатый племянник «железного канцлера» Отто фон Бисмарка (его подпись стояла под обращением «К немецким генералам и офицерам! К народу и армии!», принятому на Учредительном собрании СНО 1 сентября 1943 г.). Экземпляр документов «За Германию против Гитлера», изданных к началу конференции, подписан мне лично Генрихом фон Айнзиделем ${ }^{13}$. Мое выступление было посвящено научной деятельно-

${ }^{9}$ Визит Канцлера Аденауэра в Москву 8-14 сентября 1955 г. Документы и материалы. М.: Права человека, 2005. С. 52.

10 Петелин Б.В. Плен и политика: ХДС/ХСС и проблема немецких военнопленных в 1945-1955 гг. // Проблемы военного плена: история и современность. Материалы Международной научно-практической конференции 23-25 октября 1997 г., г. Вологда. Ч. 2. Вологда: Вологодский институт повышения квалификации и переподготовки педагогических кадров, 1997. С. 148-152.

${ }^{11}$ Die Protokolle des CDU-Bundesvorstsnds 1953-1957. Droste Verlag: Düsseldorf, 1990. S. 598-599.

${ }^{12}$ Конасов В.Б. Судьбы немецких военнопленных в СССР... Вологда, 1996. С. 174.

13 За Германию - против Гитлера! Документы и материалы о создании и деятельности Национального комитета «Свободная Германия» и Союза немецких офицеров. Мемориаль- 
сти вологодского профессора А.С. Бланка, оказавшего огромное влияние на становление российской германистики ${ }^{14}$. Александр Соломонович был также одним из первых, кто обратился к истории военного плена и опубликовал в ФРГ свое исследование о немецких военнопленных ${ }^{15}$.

В Вологде я поделился своими впечатлениями о конференции в Красногорске с Виктором Конасовым. Так как среди специалистов по отечественной истории мало кто занимался исследованием военного плена, Виктору Борисовичу не оставалось ничего другого, как стать «своим» среди российских германистов. Такой случай вскоре ему представился: в ноябре 1995 г. в Красногорске состоялась очередная научно-практическая конференция, посвященная 50-летию окончания войны и завершению деятельности НКСГ, на которой присутствовал и выступил с докладом вологодский историк Виктор Конасов (в программу конференции вошел и мой доклад «Судьбы иностранных военнопленных в отечественной историографии», но обстоятельства не позволили мне принять в ней участие) ${ }^{16}$. Именно здесь, как справедливо отмечено в «сборнике его памяти», он «впервые соприкоснулся с широким кругом российских и зарубежных ученых»..., а «завязанные тогда контакты переросли в длительное и плодотворное сотрудничество» ${ }^{17}$.

Большую помощь и поддержку в научной работе Виктору Борисовичу оказал известный российский историк-германист Александр Иванович Борозняк. Я познакомился с ним еще в студенческие годы, когда профессор А.С. Бланк создавал в Вологде Проблемное объединение по германской истории. Молодой кандидат исторических наук А.И. Борозняк стал ближайшим сподвижником вологодского профессора, а Вологда - городом, который навсегда остался близким и родным для него ${ }^{18}$.

ный музей немецких антифашистов. Москва; Красногорск: Мемориальный музей немецких антифашистов, 1993.

${ }^{14}$ Петелин Б.В. Деятельность Национального комитета «Свободная Германия» в исторических трудах А.С. Бланка // Сборник материалов российско-германской научнопрактической конференции. Москва; Красногорск 7-9 сентября 1993 г. (серия С-1). Красногорск, 1994. C. 123-129.

${ }^{15}$ Blank $A$. Die deutschen Kriegsgefangenen in der UdSSR. Köln: Pahl-Rugenstein Verlag, 1979.

16 Конасов В.Б. «Узники войны»: попытки решения проблемы на дипломатическом уровне // Трагедия плена: сб. материалов Международной научно-практической конференции «Окончание войны, завершение деятельности НКСГ/СНО и начало репатриации военнопленных», Москва - Красногорск 31 октября - 2 ноября 1995 г. Красногорск: Мемориальный музей немецких антифашистов, 1996. С. 138-141.

${ }^{17}$ Историк и его время. Памяти профессора В.Б. Конасова... Вологда, 2010. С. 9.

${ }^{18}$ Петелин Б.В. Вологда в жизни и научной деятельности Александра Ивановича Борозняка // Преодоление прошлого в Германии и России: опыт и уроки на будущее (памяти профессора А.И. Борозняка): материалы Международной научной конференции (16-17 февраля 
Свою книгу о немецких военнопленных Виктор Конасов переслал профессору А.И. Борозняку в Липецк, где тот преподавал в местном институте. Александр Иванович в ответном письме поблагодарил за присланную книгу, особо отметив «нетрадиционную структуру книги, в которой сплетаются жанры научной монографии и собрания документов». Так как А.И. Борозняк по роду своей научной деятельности часто бывал в Германии, то именно с его слов немецкие историки узнали о «вологодском капитальном издании» ${ }^{19}$. Профессор А.И. Борозняк поддержал не только книгу, а пообещал быть у Виктора Конасова на защите докторской диссертации в сентябре 1998 г. в Институте военной истории. Официальным оппонентом стал другой специалист по Германии ярославский профессор М.Е. Ерин. Авторитет известных российских германистов, несомненно, сыграл свою положительную роль при обсуждении диссертации на такую острую социально-политическую тему, как «Политика Советского государства в отношении немецких военнопленных (1941-1956 гг. $)^{20}$.

Успешную защиту докторской диссертации случайной не назовешь. В 1995-1997 гг. во многом благодаря энергичной деятельности Виктора Борисовича в Вологде удалось провести ряд значительных научных мероприятий. Только в 1995 г. состоялись две научные конференции, посвященные 50-летию Победы в Великой Отечественной войне. Вместе с вологодскими историками в них приняли участие не только специалисты по отечественной истории, но и историки-германисты. Мне уже приходилось отмечать в своих публикациях, что в 90-е гг. прошлого века Вологда «вернулась» в русло германских исследований, связанных не только с историей войны и плена, но и германской политикой ХДС/ХСС, канцлера ФРГ Гельмута Коля, одного из главных творцов объединения Германии ${ }^{21}$.

Наиболее значимым и представительным мероприятием стала Международная научная конференция «Проблемы военного плена: история и современность», прошедшая в Вологде 23-25 октября 1997 года. Во многом благодаря В.Б. Конасову, его умению вести диалог с городскими властями, работа конференции получила высокую оценку среди российской и зарубежной научной

2017, г. Липецк). Липецк: ЛГПУ имени П.П. Семенова-Тян-Шанского, 2017. С. 23-30; Данный материал размещен также на сайте российско-германского Семинара "Vereinigung": www. vereinigung.ru, 01.03.2017.

${ }^{19}$ См.: Историк о судьбах немецких военнопленных в СССР: [рецензии и отзывы на книги В.Б. Конасова]. М.: Институт военной истории Министерства обороны Российской Федерации 1997.

${ }^{20}$ Историк и его время. Памяти профессора В.Б. Конасова... Вологда, 2010. С. 507.

${ }^{21}$ Петелин Б.В. Историческая германистика в Вологде: предварительные итоги // Новейшая история Германии. Труды молодых ученых и исследовательские центры. М.: КДУ, 2007. С. 357-365; Данная публикация размещена также на сайте российско-германского семинара "Vereinigung": www. vereinigung.ru, 12. 04. 2012. 
общественности. По ее итогам был издан сборник в двух частях ${ }^{22}$. Исследование истории военного плена привело к созданию в Вологде Международного общества «Русский плен», куда вошли представители от России, Украины, Австрии, Германии, Швейцарии, Финляндии.

В июне 1995 г., в год 50-летия окончания войны в Европе, Виктор Конасов впервые посетил Германию. Вместе с директором Вологодского института развития образования профессором В.В.Судаковым они приняли участие в 26 Кирхентаге (Deutscher Evangelischer Kirchentag) в Гамбурге (14-18 июня), проводимом евангелической церковью раз в два года. Разумеется, их участие не было связано с религиозной деятельностью. Ученые из Вологды развернули выставку «Немецкие военнопленные в Вологодской области», которая приковала внимание многих немцев, особенно тех, чьи родственники или они сами имели отношение к военному прошлому ${ }^{23}$. Слова благодарности, высказанные в адрес вологжан, лишь укрепили уверенность Виктора Конасова в продолжение исследования истории военного плена. Кстати, в те же сроки в Германии находился Патриарх РПЦ Алексий II, прибывший по приглашению Совета ЕЦГ, что стало удобным поводом для установления личных контактов с высшими иерархами обоих немецких церквей, архиепископом кельнским кардиналом Иоахимом Майснером и председателем германской Епископальной конференции Карлом Леманом ${ }^{24}$.

Через два года, при содействии Губернатора Вологодской области В.Е. Позгалева ${ }^{25}$, профессор В.В. Судаков и доцент В.Б. Конасов снова были на очередном Кирхентаге 18-23 июня 1997 г. в Лейпциге, продолжив тем самым свою гуманистическую акцию. И вновь делегация Русской Православной Церкви во главе с Преосвященным архиепископом Берлинским и Германским Феофаном принимала участие в мероприятиях 27-го Немецкого Евангелического Кирхентага, о чем сообщил Митрополит Смоленский и Калининградский Кирилл (с 01.02.2009 г. Патриарх РПЦ), Председатель Отдела внешних церковных сношений, на заседании Священного Синода 17 июля 1997 г. ${ }^{26}$ Как видим, интересы

${ }^{22}$ См.: Проблемы военного плена: история и современность. Материалы Международной научно-практической конференции 23-25 октября г. Вологда. Ч. 1; Ч. 2. Вологда: Вологодский институт повышения квалификации и переподготовки педагогических кадров, 1997.

${ }^{23}$ Историк и его время. Памяти профессора В.Б. Конасова... Вологда, 2010. С. 9.

${ }^{24}$ Иерусалимский В.П. Католическая и лютеранская церкви в Германии на пороге XXI в. URL: http://www.religio.ru/relisoc/200.html. Дата обращения 17.06.2018.

${ }^{25}$ См.: Историк о судьбах немецких военнопленных в СССР: [рецензии и отзывы на книги В.Б. Конасова]. М.: Институт военной истории Министерства обороны Российской Федерации, 1997.

26 Заседание Священного Синода 17 июля 1997 г.: mospat.ruarchive/ru1997/7/. Дата обращения 17.06.2018. 
вологодского историка Виктора Конасова не расходились с миссией Русской Православной Церкви в Германии.

Виктора Борисовича интересовала судьба не только немецких военнопленных. Так, нами была подготовлена статья о роли Швеции в облегчении участи советских военнопленных, так как в годы войны Советский Союз напрямую с Германией никаких переговоров не вел ${ }^{27}$. Занимался он и польскими военнопленными, находившимися на территории СССР с начала Второй мировой войны $^{28}$. Следует отметить, что немало поляков в годы войны воевали в составе вермахта против Красной Армии (в плен было взято более 60 тыс. поляков, больше, чем итальянцев - союзников фашистской Германии). Была и другая категория польских граждан - «спецпереселенцы», депортированные в СССР с началом польской кампании в сентябре 1939 г. На территории Вологодской области, как пишет Анна Дембовска, находилось 13262 депортированных польских гражданина (в основном в Леденгском и Тотемском районах). В августе 1941 г. практически все они были освобождены по амнистии ${ }^{29}$.

Уже после защиты докторской диссертации мы с Виктором Конасовым решили подготовить и издать учебное пособие для студентов по истории военного плена и движения Сопротивления против национал-социализма. Необходимость такого пособия была очевидной: в Вологодском педагогическом университете мы вели спецкурсы, а соответствующей учебной литературы не было. К сожалению, реализовать полностью замысел не удалось. В 2000 г. была издана лишь первая часть под общим названием «Сопротивление и плен» ${ }^{30}$.

Разумеется, основная научная деятельность профессора В.Б. Конасова была направлена на изучение отечественной истории. Доклады, выступления, статьи, книги, в большинстве своем основанные на архивных материалах, регулярно появлялись в печати. Работая в Вологодском институте права и экономики, Виктор Борисович оставил свой след в изучении особенностей пенитенциарной системы в СССР и России, что имело немалое практическое значение. Важным

${ }^{27}$ Конасов В.Б., Петелин Б.В. Роль Швеции в облегчении участи советских военнопленных в годы второй мировой войны // Европейский Север в культурно-историческом процессе. К 625-летию города Кирова Материалы Международной конференции. Киров: Кировский областной краеведческий музей. Шведский культурный центр, 1999. С. 138-141.

${ }^{28}$ Конасов В.Б., Кузьминых А.Л. В плену страны Советов. Польские военнопленные в Грязовецком лагере НКВД // Новый Часовой: Русский военно-исторический журнал. 2002. C. 55-79.

${ }^{29}$ Дембовска А. Поляки на Севере России. Альбом о польских местах памяти. СПб.: Академия, 2011. С. 189.

${ }^{30}$ Конасов В.Б., Петелин Б.В. Сопротивление и плен: документы и материалы по истории антифашистского движения Сопротивления и военного плена в Германии и СССР. 19331955 гг. Ч. 1. ИПК и ППК. Вологда: Вологодский институт развития образования, 2000. 
в его деятельности было краеведческое направление, ориентированное не только на студентов, но и на школьников, с которыми профессор всегда общался доступно, свободно и эмоционально. Его, как и других преподавателей, не могла не волновать складывающаяся ситуация с воспитанием подрастающего поколения $^{31}$.

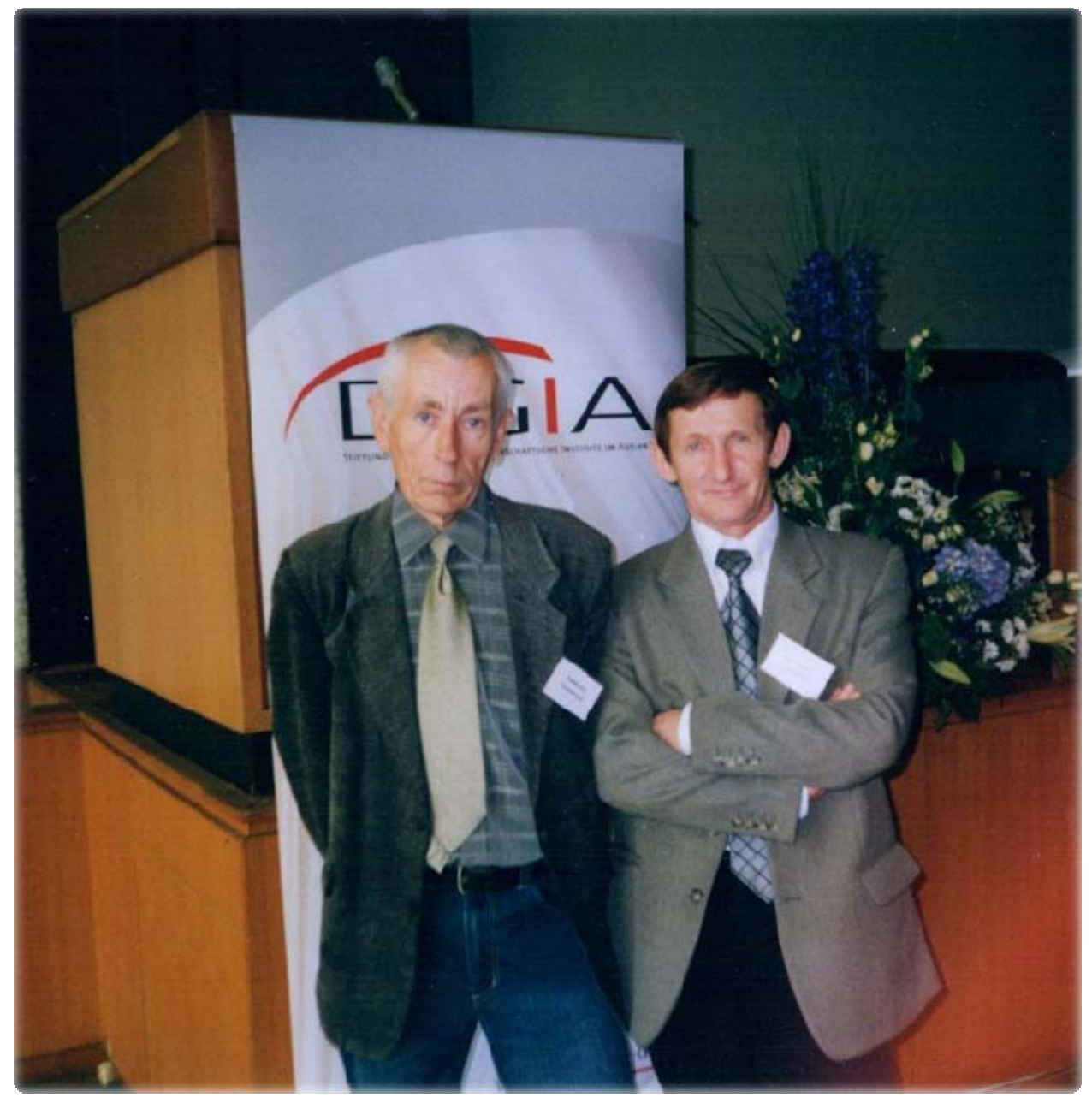

Доктор исторических наук, профессор кафедры всеобщей истории ВГПИ Б.В. Петелин и доктор исторических наук, профессор ВИПЭ ФСИН В.Б. Конасов на открытии

Германского исторического института в Москве в здании ИНИОН РАН, 12.09.2005 г.

Вместе с тем сохранялась приверженность к германской истории. Была опубликована статья в научном сборнике «Германия и Россия», издаваемом в Воронеже, где в те годы активно действовал региональный Центр германских исследований ${ }^{32}$. В мае 2001 г. Виктор Борисович участвовал в представитель-

${ }^{31}$ Конасов В.Б. Духовность как важнейшее условие выживание русского народа // Духовность как основа общения: образование и культура. Материалы научно-практической конференции. Вологда, 2002. С. 181-187.

${ }^{32}$ Конасов В.Б. Историография вопроса о трудовом использовании немецких военнопленных в СССР // Германия и Россия. Вып. 3. Воронеж, 2000. С. 211-214. 
ной Международной научной конференции «Вехи российско-германских отношений 40-90 годы XX века» в Волгограде, по результатам которой был издан сборник статей ${ }^{33}$. Волгоград, когда не стало профессора А.С. Бланка, фактически перенял эстафету германских исследований. Местный педагогический институт взял на себя инициативу проводить научные конференции историковгерманистов с участием исследователей из ГДР. Я еще захватил то время и могу сказать, что там и тогда было все: и наука, и продуманная культурная программа. Состоявшаяся в октябре 1989 г. конференция, посвященная 40-летнему юбилею ГДР, оказалась последней. Мне, выступавшему с докладом по партийно-политической деятельности ХДС/ХСС, были понятны грустные взгляды восточногерманских историков: через месяц исчезнет Берлинская стена, а там и сама ГДР навсегда уйдет в историю.

Но установившиеся связи между российскими и немецкими историками не исчезли. И в Германии, и в России сохранился научный интерес к прошлому своих стран, развитию российско-германских связей и отношений, современной политике и деятельности партий и общественных организаций. Свидетельством тому плодотворная деятельность Западносибирского Центра германских исследований, регулярно издающего научные сборники «Германские исследования в Сибири», первый из которых вышел в 2001 г. ${ }^{34}$.

Мы в Вологде по ряду субъективных причин не могли развернуть столь масштабно свою международную деятельность. Однако установившиеся связи с Фондом им. Конрада Аденауэра (ХДС) и Фондом им. Ханнса Зайделя (ХСС), которые поддерживаются до сих пор, позволили нам осуществить издание нескольких монографий и провести в 2000-е гг. в Вологде ряд представительных научных конференций. Первая из них состоялась 17-18 октября 2005 г.: «Установление дипломатических отношений между СССР и ФРГ. Немецкие военнопленные в СССР». Конференция была задумана к 50-летнему юбилею визита Федерального канцлера Конрада Аденауэра в СССР, в ходе которого были установлены дипломатические отношения между двумя странами. Но Виктор Борисович настоял на том, что следует обозначить «проблему немецких военно-

${ }^{33}$ Конасов В.Б. Вехи российско-германских отношений (40-0-е годы ХХ века): материалы Междунар. науч. конф., г. Волгоград, 24-27 мая 2001. Волгоград: Волгоградский государственный университет, 2001. С. 127-133.

${ }^{34}$ Петелин Б.В. ХДС/ХСС и становление новой партийно-политической системы в Восточной Германии 1989-90 гг. // Германия и Россия в XX веке: две тоталитарные диктатуры, два пути к демократии: материалы международной научной конференции (г. Кемерово, 1922 сентября 2000 г.). Кемерово: Кемеровский государственный университет, 2001. С. 427436; Он же. Революция 1989 г. в ГДР в оценках российских и немецких исследователей // Разрушение и возрождение в истории Германии и России: сборник статей международной научной конференции (г. Томск, 23-25 сентября 2009 г.). Томск: Томский университет, 2010. C. 225-232. 
пленных», хотя ее вполне можно было рассмотреть в рамках анализа переговоров в Кремле. Тем самым, название конференции не было бы перегруженным. Впрочем, каких-либо суждений по этому поводу участниками конференции не высказывалось.

В сентябре 2005 г., за месяц до конференции в Вологде, в научном сообществе российских историков произошло знаменательное событие: в Москве состоялось торжественное открытие Германского исторического института. Его организатором и первым Директором ГИИ был немецкий профессор Бернд Бонвеч, которого я знал по Германии с 2000 года. Д-р Бонвеч был заведующим кафедрой восточноевропейских исследований Рур-Университета в Бохуме (земля Северный Рейн-Вестфалия), сотрудничавшей с рядом российских университетов. На его кафедре в 2002 г. как стипендиат Фонда им. Конрада Аденауэра я проходил стажировку. И хотя мои интересы не совпадали с исследованиями немецкого профессора, но во всем остальном я приобрел авторитетного знающего ученого и друга. Могу со всей определенностью сказать, что таким другом он был для всех российских историков-германистов. Естественно, что я получил приглашение на открытие Германского исторического института в Москве. Когда об этом я сказал Виктору Борисовичу, то он просто расстроился. Нет, за меня он, конечно, был рад: среди германистов я «свой», но неужели нельзя ему, внесшему существенный вклад в изучение военного плена, быть на открытии? Он буквально уговорил меня тут же с его домашнего телефона позвонить Директору Бонвечу с ходатайством, что я и сделал. Вопрос был решен в течение нескольких минут. На открытие ГИИ в Москву мы поехали вместе. Размещение, кстати, было в гостинице «Россия». Все остальное прошло на высочайшем уровне. Последняя встреча с д-ром Бонвечем состоялась в Москве, в гостинице «Метрополь», на торжественном мероприятии по случаю 10 -летнего юбилея ГИИ. В октябре 2017 г. Бернда Бонвеча не стало.

Вернемся к «нашим» конференциям. Научный семинар, как в итоге мы назвали наше мероприятие в октябре 2005 г., прошел успешно. В его работе приняли участие такие известные российские ученые, как Н.В. Павлов, А.М. Филитов, Ф.И. Новик, Б.М. Туполев (все - Москва), А.Е. Епифанов (Волгоград), В.С. Павлов (Нижний Новгород), М.Н. Супрун (Архангельск), В.Л. Черноперов (Иваново), научный сотрудник ГИИМ, доктор М. Уль, доктор А. Хильгер (Гамбург), другие авторитетные специалисты. По «немецким военнопленным в СССР» организовали «круглый стол». Руководитель Санкт-Петербургского филиала Фонда им. Конрада Аденауэра г-жа Э. Бауэр, по образованию историк, принявшая самое активное участие в работе Семинара, высоко оценила работу 
нашего Семинара. По его итогам под редакцией В.Б. Конасова и Б.В. Петелина был издан научный сборник ${ }^{35}$.

\section{Заключение}

В октябре 2009 г. мы провели очередную конференцию в Вологде в формате «научного семинара» по теме: «Политические повороты в советско-германской истории: 1949-1989: Поиски. Надежды. Свершения» ${ }^{36}$. Участники приехали из разных городов России и Республики Беларусь. Свое содействие в проведении традиционно оказал Фонд им. Конрада Аденауэра (Санкт-Петербург). Виктора Борисовича Конасова среди нас уже не было. За год до этого, 28 июня 2008 г., он скоропостижно скончался. Но его научные начинания, поиски, исследования были продолжены его учениками. Не забыто и его имя. Известный вологодский журналист Геннадий Акиньхов в своей книге «Прорыв» написал о Викторе Борисовиче: «А наш вологодский Конасов, открыв для себя такую тему научных изысканий, которую до него осмелились взять лишь единицы историков Советского Союза, сумел развить ее так, что эта работа стала подлинным прорывом на одном из направлений исторической науки и у нас в России, и за ее пределами» ${ }^{37}$.

Для нас важно и другое: созданный в 1998 г. при участии В.Б. Конасова музей воинской славы клуба «Алые паруса» в Вологде продолжает жить. 25 мая 2018 г. в стенах музея прошла Первая городская военно-патриотическая конференция памяти вологодского ученого - историка Виктора Борисовича Конасова $^{38}$. Подобный пример не единственный в общественной и научной жизни Вологды, и не только ее одной.

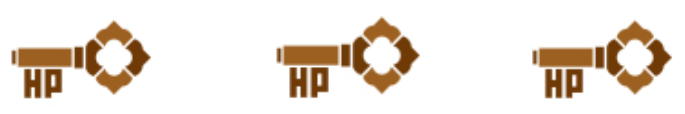

\section{Introduction}

In 2010, a scientific collection 'The Historian and his Time' was published in Vologda. It was dedicated to the memory of the Doctor of Historical Sciences, Professor

35 Установление дипломатических отношений между СССР и ФРГ. Немецкие военнопленные в СССР: Материалы Международного научного семинара (Вологда, 17-18 октября 2005 г.). Вологда: Вологодский институт права и экономики ФСИН России, 2006.

${ }^{36}$ Политические повороты в советско-германской истории: 1949-1989: Поиски. Надежды. Свершения: Материалы международного научного семинара (Вологда, 6-7 октября 2009 г.) / отв. ред. Б.В. Петелин; сост. Э. Бауэр, Б.В. Петелин. Вологда: Граффити, 2010.

${ }^{37}$ См.: Акиньхов Г.А. Прорыв. Из жизни ученых. Вологда: Права человека, 2008.

38 www.dtdm.edu.ru/музей-воинской-славы-алые-паруса-му/ 
Viktor Borisovich Konasov - in fact, to his $60^{\text {th }}$ birthday, to which he did not live only two years ${ }^{1}$. The publication turned out to be fundamental, with a wide coverage of historical topics and problems, both in domestic and foreign history. Financial support was rendered by St Petersburg office of the Konrad-Adenauer-Stiftung, which illustrates the title of our article at best. The collection attracted readers' interest, and it is still in steady demand on part of research specialists. All those who turn to its content will certainly read the materials about Viktor Borisovich himself, his lifetime, pedagogical and scientific activity.

\section{Main body}

To me, who knew Viktor Konasov closely, his appeal to the problem of military captivity - German soldiers and officers being in Soviet captivity - seems natural and logical, given his focus on creative research in the study of new topics in the history of World War II $^{2}$. A real scientist has to have some kind of 'historical instinct' (this is sometimes called a 'conjunctural approach') and to respond to time requests. After the collapse of the Soviet Union, due to the beginning of the revision of many events in the domestic history, access to previously classified documents increased. This 'window' soon slammed shut; however for pushing researchers, such as Viktor Konasov, this option was quite enough. The author told me that when he started working in the Russian State Military Archive (at that time - the Special Archive) in the autumn of 1991; before that no one was able to read most of the classified records or top secret documents. Only a few fell earlier into the hands of one or two people. Thus, he called colonel general Dmitri Volkogonov, who was a member of the commission on declassification of documents in the 1990s, and at the same time chairman of the Presidential Commission for the Declassification of Documents regarding prisoners of war, internees and missing people. The work of Viktor Konasov in the Archive of Foreign Policy of the Russian Federation was fruitful as well. The collected materials (where the work was extremely complex and difficult) formed the basis of his most famous and popular book 'The Fates of German Prisoners of War in the USSR ....'?

We will refer to the book later. The path to writing this book was not straight, however it cannot be called winding either. Viktor Konasov showed interest in military subjects in his student years, when he began to collect letters and memoirs of the

${ }^{1}$ See: The Historian and His Time. In memory of Professor V.B. Konasov: A collection of articles. Vologda: Graffiti, 2010.

${ }^{2}$ B.V. Petelin, "Professor V.B. Konasov and the problems of studying and teaching the history of the World War II in the context of modernity", in The historian and his time. In memory of Professor V.B. Konasov: A collection of articles (Vologda: Graffiti, 2010), 14-23.

${ }^{3}$ V.B. Konasov, The fate of German prisoners of war in the USSR: Diplomatic, legal and political aspects of the problem. Essays and documents (Vologda: Institut povysheniya kvalifikatsii i perepodgotovki kadrov, 1996). 
Vologda front-line soldiers. After graduating from the Faculty of History, Vologda State Pedagogical Institute, he worked in urban educational institutions, and since 1987 he was busy preparing his $\mathrm{PhD}$ thesis devoted to the activities of the military medical-sanitary service of the Red Army during the Great Patriotic War. In 1990, he earned his degree. For some time, we worked together at the same department in the Vologda Dairy Farming Institute, and later we met 'within the walls' of the Vologda State Pedagogical University. In 1991, Viktor Konasov prepared and published a small brochure 'Declassified', which raised the issue of German prisoners of war in the USSR ${ }^{4}$. Starting with it, one can say, the candidate of historical sciences V.B. Konasov began to deal with the History of Germany, even if it was related to the Soviet territory during the said war.

On the one hand, as we are talking about the Germans, this is a topic for historians-Germanists, who study the History of Germany. However on the other hand - the captivity was still 'Soviet', and everything that was associated with it, was determined by the Soviet authorities, laws, orders and regulations. This was the main difficulty of the study ... Subsequently, Viktor Borisovich was repeatedly asked: "Who do you work for? Germany or Russia?" In the above-mentioned brochure, the author reproaches Stalin's leadership for the fact that the USSR did not join the Geneva Convention relative to the Treatment of Prisoners of War and amelioration of the condition of the wounded and sick in armies. This, allegedly, untied the Nazis persecution of Soviet prisoners of war. Weak argument it was! Regardless of the fact whether the Soviet Union was willing to sign the Geneva Convention (1929) or not, the fate of the Red Army men who were captured by the Germans would have remained unchanged. The author's judgments regarding 'excessive cruelty' in dealing with German prisoners of war appeared to be incorrect. We will cite only one example: according to the approved norms of 1941, 700 grams of bread were given to them daily; and additionally, other products that disappeared for Soviet citizens during the war years. Indeed, the USSR did not sign the Geneva Conventions (1929), however did not have their compliance either (on $1^{\text {st }}$ July 1941, the Soviet government adopted the 'Regulations on POWs', which did not contradict global norms and international humanitarian law in general).

Let us get back to the book 'The Fates of German POWs in the USSR ...'. It aroused a lot of interest indeed. Responses and reviews appeared in various publications. I also provided my comments by publishing a short article in the Vologda newspaper Russkii Sever. Without retelling the contents of the book depicting the fate of German prisoners of war, I noted that "Soviet captivity was more humane", which was evident from the documents cited in the book. As a historian-Germanist, I

${ }^{4}$ V.B. Konasov, Declassified: (to the history of German prisoners of war in the USSR) (Vologda: Vologda State Pedagogical Institute, group 'Search', 1991).

${ }^{5}$ Russkii Sever, $7^{\text {th }}$ May, 1996. 
was attracted more by the description of the Germans' return homeland, on which the author informed us in the second chapter of his book ${ }^{6}$. The return of prisoners of war occurred almost immediately after Nazi Germany surrendered. First of all, those wounded, sick and disabled, which seemed quite humane; however as a matter of fact, those who returned homeland faced problems that led to many committing suicide ${ }^{7}$.

The 'last page in the history' of 'Soviet captivity' was turned over in September 1955, during the official visit of German Chancellor Konrad Adenauer to Moscow. Work in the archives helped Viktor Borisovich to name the real numbers of former German prisoners of war who were in the camps of the USSR at that time - 9626 'detainees ${ }^{8}$. Adenauer linked the establishment of diplomatic relations with the USSR with the liberation of all "held Germans", at the same time announcing their number - no less than 130 thousand, although no lists were provided. According to the chancellor, the idea itself was unbearable, that ten years after the end of the war, people dragged into the whirlpool of military events "are still detained far from their families, homeland and their normal peaceful labour"" It should be said that Konrad Adenauer then voiced the position of his party - the CDU, of which he was the chair$\operatorname{man}^{10}$.

Returning from the prolonged captivity, the Germans 'were grateful' to Adenauer, although the decision to release them was made in the USSR even before the chancellor's visit. Adenauer himself, at a meeting of the National board of the CDU held on $30^{\text {th }}$ September 1955 described in great detail his visit to Moscow, his impressions of the talks with the Soviet leaders, without forgetting to characterize each of them, and also impressions about Moscow and Muscovites. There was no hostility in his words. The chancellor was pleased: almost half of the Germans participating in the poll (48\%) approved the negotiations in the Kremlin, and only $9 \%$ considered them 'failed" ${ }^{11}$. In 1956, the last prisoners of war were able to leave the USSR -

${ }^{6}$ V.B. Konasov, The Fates of German Prisoners of War in the USSR..., 123-74.

${ }^{7}$ See: E.V. Obraztsova, "The resocialization of German prisoners of war after their return from the USSR (1945-1955)" (PhD diss., Voronezh, 2017). The author highlights the research of V.B. Konasov, who was able to comprehensively analyze the fate of German prisoners of war. Ibid, 4-5.

${ }^{8}$ V.B. Konasov, The fate of German Prisoners of War in the USSR..., 173.

${ }^{9}$ Visit of the Chancellor of Adenauer to Moscow on 8-14 th September 1955. Documents and materials (Moscow: Human Rights, 2005), 52.

${ }^{10}$ B.V. Petelin, "Captivity and politics: CDU / CSU and the problem of German prisoners of war in 1945-1955", in Problems of military captivity: History and modernity. Materials of the international scientific and practical conference on 23-25 th October 1997, Vologda. Part 2 (Vologda: Institut povysheniya kvalifikatsii i perepodgotovki kadrov, 1997), 148-52.

11 Die Protokolle des CDU-Bundesvorstsnds 1953-1957 (Droste Verlag: Düsseldorf, 1990), 598-99. 
749 people, who "as it was found out, could not be placed in prison wards in their homeland..." $"$.

Even before the publication of V.B. Konasov's book, the problem of military captivity became one of the main issues at the international conference dedicated to the $50^{\text {th }}$ anniversary of the creation of the National Committee for a Free Germany. The conference was held in Krasnogorsk, near Moscow, in the building of the Memorial Museum of German Anti-Fascists (in 1943 the former Central School anti-fascists for foreign prisoners of war), which in 2005 became a branch of the Central Museum of the Great Patriotic War of 1941-1945. Among the participants of the conference, there were well-known Russian and German historians, as well as former prisoners of war who were part of the NKFD (Nationalkomitee Freies Deutschland - National Committee for a Free Germany) and the BDO (Bund Deutscher Offiziere - the German Officers League). Perhaps the most prominent representative at the conference was Count Heinrich von Einsiedel, a great-grandson of the 'Iron Chancellor' Otto von Bismarck (his signature was under the petition "The German Generals and Officers! To the People and the Army!" adopted at the Constituent Assembly of the BDO on $1^{\text {st }}$ September 1943). A copy of the documents 'For Germany - against Hitler!' published at the beginning of the conference, was signed personally by Heinrich von Einsiedel $^{13}$. My speech was devoted to the scientific work of the Vologda professor A.S. Blank, who had a great influence on the development of German studies in Rus$\mathrm{sia}^{14}$. Aleksandr Solomonovich was also one of the first people who turned to the history of military captivity and published his study on German prisoners of war in Germany ${ }^{15}$.

In Vologda, I shared my impressions of the conference in Krasnogorsk with Viktor Konasov. Since amongst the experts in Russian history, few people were engaged in the study of military captivity, Viktor Borisovich had no choice rather than to fit in the circle of Russian Germanists. He had such an occasion soon: in November 1995, another scientific and practical conference was held in Krasnogorsk devoted to the $50^{\text {th }}$ anniversary of the end of World War II and the completion of the activities of the NKFG; Vologda historian Viktor Konasov attended the said conference and presented his report (the conference programme also included my report 'The fate of foreign prisoners of war in Soviet historiography', however the circumstances did not

${ }^{12}$ V.B. Konasov, The Fate of German Prisoners of War in the USSR..., 174.

${ }^{13}$ For Germany - against Hitler! Documents and materials on the creation and activities of the National Committee for a Free Germany and the League of German Officers. Memorial Museum of German anti-fascists (Krasnogorsk: Memorial Museum of German anti-fascists, 1993).

${ }^{14}$ B.V. Petelin, "The activities of the National Committee for a Free Germany in the historical works of A.S. Blank", in Collected materials of the Russian-German scientific-practical conference. Moscow; Krasnogorsk 7-9 ${ }^{\text {th }}$ September 1993 (series S-1) (Krasnogorsk, 1994), 123-29.

${ }^{15}$ A. Blank, Die deutschen Kriegsgefangenen in der UdSSR (Köln: Pahl-Rugenstein Verlag, 1979). 
allow me to take part in it) ${ }^{16}$. It was there, as it was rightly noted in the "collection of his memory', that he came into contact with a wide circle of Russian and foreign scientists for the first time ..., and that the established rapport further grew into a long and fruitful cooperation ${ }^{17}$.

A famous Russian historian-Germanist Alexander Ivanovich Borozniak was of great help and provided support in the scientific work of Viktor Borisovich. I met him when I was a student, when Professor A.S. Blank created the Association on German History in Vologda dealing with problems in this area. Young Candidate of Historical Sciences A.I. Borozniak became the closest associate of the Vologda professor, and Vologda remained a city forever close and dear to him $^{18}$.

Viktor Konasov sent his book about German prisoners of war to professor A.I. Borozniak in Lipetsk, where he taught at the local institute. In his reply, Alexander Ivanovich thanked for the book, especially noting the "non-traditional structure of the book, in which the genres of the scientific monograph and the collection of documents were intertwined". Since A.I. Borozniak often went to Germany due to his scientific activity, it was according to his information that German historians learned about 'Vologda capital edition'19. Professor A.I. Borozniak backed up not only the idea of the book, but promised to accompany Viktor Konasov at the defense of his doctoral thesis in September 1998 at the Institute of Military History. The official opponent was another expert in Germany, professor M.E. Erin from Yaroslavl. The authority of the well-known Russian Germanists undoubtedly played a positive role in the discussion of the thesis on such an acute socio-political theme as 'The policy of the Soviet state in relation to German prisoners of war (1941-1956) ${ }^{20}$.

Successful defense of a doctoral thesis was no accident. In 1995-97, in many respect thanks to the energetic activity of Viktor Borisovich, a number of significant scientific events were held in Vologda. Only in 1995, two scientific conferences were

${ }^{16}$ V.B. Konasov, "Prisoners of War': Attempts to solve the problem at the diplomatic level", in Tragedy of captivity: Collected materials of the International Scientific and Practical Conference 'End of the war', the completion of the activities of the NKFG / BDO and the beginning of the repatriation of prisoners of war', Moscow - Krasnogorsk $31^{\text {st }}$ October $-2^{\text {nd }}$ November1995 (Krasnogorsk, 1996), 138-41.

${ }^{17}$ The historian and his time. In memory of Professor V.B. Konasov, 9.

${ }^{18}$ B.V. Petelin, "Vologda in the life and scientific activities of Alexander Ivanovich Borozniak" in Overcoming the past in Germany and Russia: Experience and lessons for the future (in memory of Professor A.I. Borozniak): Materials of the International Scientific Conference (16-1 $7^{\text {th }}$ February 2017, Lipetsk) (Lipetsk: P.P. Semenov-Tian-Shanskii LSPU, 2017), 23-30; This material is also available on the website of the Russian-German Seminar 'Vereinigung': www.vereinigung.ru, 01.03.2017.

${ }^{19}$ See: "The historian about the fate of German prisoners of war in the USSR", reviews and opinions on the books of V.B. Konasov. (Moscow: Institute of Military History of the Ministry of Defense of the Russian Federation, 1997).

${ }^{20}$ The Historian and His Time. In memory of Professor V.B. Konasov, 507. 
held devoted to 50 Years of the Victory in the Great Patriotic War. Together with the Vologda historians, who were not only specialists in Russian history, however also historians-Germanists, took part in them. I have already noted in my publications that in the 1990s, Vologda 'returned' to the mainstream of German studies related not only to the history of war and captivity, but also to the German policy of the CDU / CSU, the Chancellor of Germany Helmut Kohl, one of the main 'architects' of the German reunification $^{21}$.

The most significant and representative event was the International Scientific Conference 'The Problems of Military Captivity: History and Modernity', held in Vologda on $23-25^{\text {th }}$ October 1997. Thanks to V.B. Konasov, his ability to conduct a dialogue with the city authorities, the work of the conference was highly appreciated among the Russian and foreign scientific community. As a result, the collection was published in two parts ${ }^{22}$. The study of the history of military captivity led to the establishment in Vologda of the International Society 'Russian captivity', which included representatives from Russia, Ukraine, Austria, Germany, Switzerland and Finland.

In June 1995, the year of the $50^{\text {th }}$ anniversary of Victory in Europe Day, Victor Konasov visited Germany for the first time. He and the director of the Vologda Institute for the Development of Education Professor V.V. Sudakov took part in the $26^{\text {th }}$ Deutscher Evangelischer Kirchentag in Hamburg (14-18 ${ }^{\text {th }}$ June), held by the Evangelical Church every two years. It goes without saying, their participation was not related to religious activities. The scientists from Vologda launched an exhibition 'German prisoners of war in Vologda region', which attracted attention of many Germans, especially those whose relatives or them themselves had to do with the military past $^{23}$. The words of gratitude addressed to the Vologda citizens only strengthened the confidence of Viktor Konasov in continuing with the study of history of military captivity. Incidentally, Patriarch Alexii II of the Russian Orthodox Church visted Germany at the same time, arriving at the invitation of the European Centralized Council, which was a convenient occasion for establishing personal contacts with the highest hierarchs of both German churches, Archbishop Joachim Meisner of Cologne, and Karl Leman, former head of Germany's Catholic Bishops' Conference ${ }^{24}$.

${ }^{21}$ B.V. Petelin, "Historical Germanic studies in Vologda: Preliminary results", The newest history of Germany. Proceedings of young scientists and research centers (Moscow: KDU, 2007), 357-65; This publication is also available on the website of the Russian-German seminar 'Vereinigung': www. vereinigung.ru, 12.04.2012.

22 See: Problems of military captivity: history and modernity. Materials of the International Scientific and Practical Conference 23-25 ${ }^{\text {th }}$ October, Vologda. Part 1; Part 2 (Vologda, 1997).

${ }^{23}$ The Historian and His Time. In memory of Professor V.B. Konasov, 9.

${ }^{24}$ V.P. Ierusalimskij, "The Catholic and Lutheran churches in Germany at the threshold of the $21^{\text {st }}$ century", http://www.religio.ru/relisoc/200.html. Accessed: 17.06.2018. 
Two years later, with the assistance of the Governor of Vologda Oblast V.E. Pozgaliov $^{25}$, Professor V.Sudakov and Associate Professor V.B. Konasov were again at the next Kirchentag on 18-23th June 1997 in Leipzig, thus continuing their humanistic action. Again, the delegation of the Russian Orthodox Church led by His Eminence Archbishop of Berlin and Germany Feofan took part in the events of the $27^{\text {th }}$ German Evangelical Kirchentag, as reported by Metropolitan Kirill of Smolensk and Kaliningrad (since $1^{\text {st }}$ February 2009, the Patriarch of the Russian Orthodox Church), Chairman of the Department for External Church Relations at the meeting of the Holy Synod on $17^{\text {th }}$ July $1997^{26}$. As we can see, the interests of the Vologda historian Viktor Konasov did not differ from the mission of the Russian Orthodox Church in Germany.

Viktor Borisovich was interested in the fate of not only German prisoners of war. Thus, we prepared an article on the role of Sweden in facilitating an exchange of information on the fate of Soviet prisoners of war, since during the war years the Soviet Union did not negotiate directly with Germany ${ }^{27}$. He was also dealing with Polish prisoners of war, who were on the territory of the USSR since the beginning of the World War II $^{28}$. It should be noted that many Poles during the war fought in the Wehrmacht against the Red Army (more than 60 thousand Poles were taken prisoner, which is more than Italians - allies of fascist Germany). There was also another category of Polish citizens - 'special settlers' deported to the USSR at the start of the Polish campaign in September 1939. According to Anna Dembowska, there were 13,262 deported Polish citizens on the territory of the Vologda region (mainly in Ledengsk and Totma districts). In August 1941, almost all of them were released under an amnesty $^{29}$.

After defending my doctoral thesis, we decided to prepare and publish a textbook for students on the history of military captivity and the Resistance against National Socialism. The need for such a manual was obvious: at the Vologda Pedagogical University, we delivered dedicated courses, and there was no relevant educational lit-

${ }^{25}$ See: "The historian about the fate of German prisoners of war in the USSR", reviews and opinions on the books of V.B. Konasov (Moscow: Institute of Military History of the Ministry of Defense of the Russian Federation, 1997).

${ }^{26}$ Meeting of the Holy Synod on July 17, 1997: mospat.ruarchive / ru1997 / 7 /. Date of access: $17^{\text {th }}$ June 2018.

${ }^{27}$ V.B. Konasov and B.V. Petelin, "The role of Sweden in facilitating the fate of Soviet prisoners of war during World War II", in The European North in the cultural and historical process. To the $625^{\text {th }}$ anniversary of the city of Kirov Materials of the International Conference (Kirov, 1999), $138-41$.

${ }^{28}$ V.B. Konasov and A.L. Kuz'minykh, "In captivity of the country of the Soviets. Polish prisoners of war in the Griazovets camp of the NKVD" in New Sentry: Russian military history magazine (2002): 55-79.

${ }^{29}$ A. Dembowska, Poles in the North of Russia. Album about the Polish places of memory (St Petersburg, 2011), 189. 
erature. Unfortunately, the idea could not be fully implemented. In 2000, only the first part was published under the title 'Resistance and captivity'30.

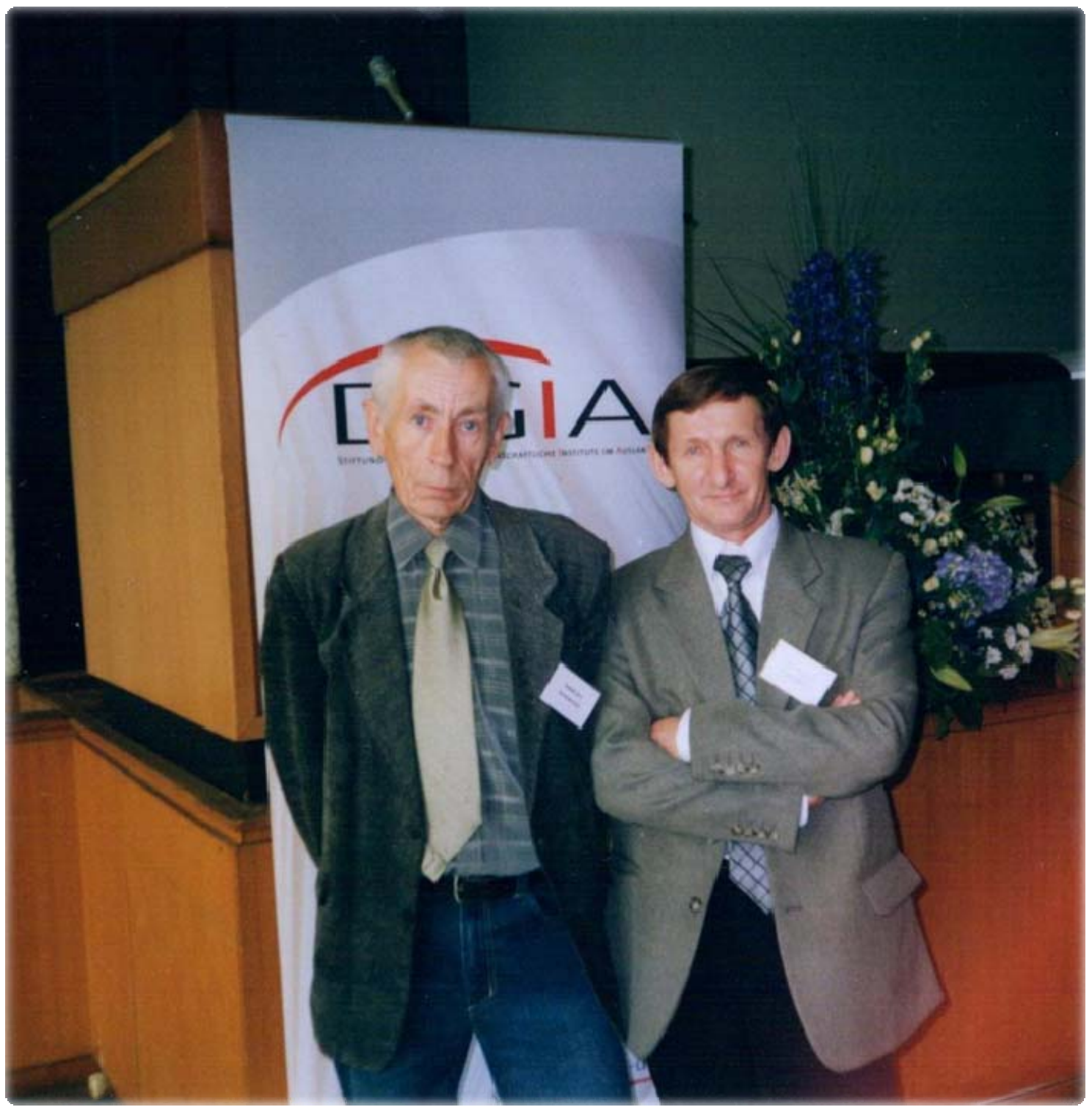

Doctor of historical sciences, professor of department of general history VGPI B.V. Petelin and doctor of historical sciences, professor of VIPE FSIN V.B. Konasov at opening of the German historical institute in Moscow in the building the INION of RAS, 12. 09. 2005

It goes without saying, the main scientific activity of Professor V.B. Konasov was aimed at studying Russian history. Reports, speeches, articles and books, mostly based on archival materials, appeared regularly in the press. Working at Vologda Institute of Law and Economics, Viktor Borisovich left his mark on the study of peculi-

${ }^{30}$ V.B. Konasov and B.V. Petelin, Resistance and captivity: documents and materials on the history of the anti-fascist resistance movement and military captivity in Germany and the USSR. 1933-1955, Part 1 (Vologda: Institut povysheniya kvalifikatsii i perepodgotovki kadrov, 2000). 
arities of the penitentiary system in the USSR and Russia, which was of considerable practical importance. Important in his work was the trend aimed at local history, orientated not only at students, but also at schoolchildren, with whom the professor always talked emotionally and freely. He, like other teachers, could not help worrying about the emerging situation involving upbringing of the younger generation ${ }^{31}$.

At the same time, adherence to German history remained. An article was published in the scientific collection 'Germany and Russia' published in Voronezh, where in those years the regional Centre for German Studies was functioning ${ }^{32}$. In May 2001, Viktor Borisovich participated in the representative International Scientific Conference 'Milestones of Russian-German Relations of the 1940-90s' in Volgograd, which resulted in the publication of a collection of articles ${ }^{33}$. When Professor A.S. Blank passed away, Volgograd in fact, took up the 'baton' of German studies. The local pedagogical institute took the initiative to hold scientific conferences of historians-Germanists with the participation of researchers from the GDR. I happened to work during that time and can say that there was everything there and then: both science and a thoughtful cultural program. The conference held in October 1989 dedicated to the $40^{\text {th }}$ anniversary of the GDR was the last one. I gave a talk on partypolitical activity of the CDU / CSU, I understood the sad views of East German historians: a month later the Berlin Wall would fall, and the GDR itself would forever go down in history.

However, the established ties between Russian and German historians have not disappeared. Both in Germany and in Russia, the scientific interest in the past of the countries, the development of Russian-German links and relations, modern politics and the activity of parties and public organizations remained. Evidence of this is the fruitful activity of the West Siberian Center for German Studies, which regularly publishes scientific collections 'German Studies in Siberia', the first of which was published in $2001^{34}$.

${ }^{31}$ V.B. Konasov, "Spirituality as the most important condition for the survival of the Russian people" in Spirituality as the basis of communication: education and culture. Materials of scientific and practical conference (Vologda, 2002), 181-87.

${ }^{32}$ V.B. Konasov, "Historiography of the question of the employment of German prisoners of war in the USSR", Germany and Russia, issue 3 (2000): 211-14.

${ }^{33}$ V.B. Konasov, Milestones of Russian-German relations (1940-90s): Materials of the international scientific conference, Volgograd, 24-27 ${ }^{\text {th }}$ May 2001 (Volgograd, 2001), 127-33.

${ }^{34}$ B.V. Petelin, "CDU / CSU and the formation of a new party-political system in East Germany in 1989-90", in Germany and Russia in the Twentieth Century: Two Totalitarian Dictatorships, Two Ways to Democracy: Proceedings of the International Scientific Conference (Kemerovo, 19-22 $2^{\text {nd }}$ September 2000) (Kemerovo, 2001), 427-36; Idem, "The 1989 revolution in the GDR in the assessments of Russian and German researchers" in Destruction and revival in the history of Germany and Russia: Collection of articles of the International Scientific Conference (Tomsk, 23$25^{\text {th }}$ September 2009) (Tomsk, 2010), 225-32. 
For a number of internal reasons, we were not able to develop our international activities on such a large scale in Vologda. However, the established links with the Conrad Adenauer Foundation (CDU) and the Hanns Seidel Foundation (CSU), which are still supported, allowed publishing several monographs and hold a number of representative scientific conferences in Vologda in the 2000s. The first of them took place on $17-18^{\text {th }}$ October 2005: 'Establishment of diplomatic relations between the USSR and Germany. German prisoners of war in the USSR'. The conference was dedicated to the $50^{\text {th }}$ anniversary of the visit of German Federal Chancellor Konrad Adenauer to the USSR, during which diplomatic relations between the two countries were established. However Viktor Borisovich insisted that the "problem of German prisoners of war" should be designated, although it could be considered in the framework of the analysis of the negotiations in the Kremlin. Thus, the name of the conference would not be overloaded. However, the participants of the conference did not express any opinion on this issue.

In September 2005, a month before the conference in Vologda, a remarkable event took place in the scientific community of Russian historians: the grand opening of the German Historical Institute Moscow. Its organizer and the first Director of the GII was the German professor Bernd Bonwetsch, whom I have known in Germany since 2000. Dr Bonwetsch was head of the Department of Eastern European Studies at the Ruhr-University in Bochum (North Rhine-Westphalia), which collaborated with a number of Russian universities. At his department, in 2002 as a fellow of the Konrad Adenauer Foundation, I took internship training. And although my interests did not coincide with the researches of the German professor, but in everything else I acquired an authoritative knowledgeable scientist and friend. I can say with all certainty that he was such a friend to all Russian historians-Germanists. Naturally, I received an invitation to open the German Historical Institute in Moscow. When I told Viktor Borisovich about this, he was simply upset. No, for me, of course, he was happy: I belonged to the Germanists, but why could not he, who had made a significant contribution to the study of military captivity by the time, be at the opening? $\mathrm{He}$ literally persuaded me immediately to call Director Bonwetsch with a request from his landline, which I did. The issue was resolved within a few minutes. We went together to the opening of the GII in Moscow. Accommodation, by the way, was in the hotel 'Russia'. Everything else was arranged at the highest level. The last meeting with Dr Bonwetsch took place in Moscow, in 'Metropol' Hotel, at a solemn event to celebrate the $10^{\text {th }}$ anniversary of the GII. In October 2017, Bernd Bonwetsch passed away.

Let us come back return to 'our' conferences. The scientific seminar, as we called our event in October 2005, was successful. Such famous Russian scientists as N.V. Pavlov, A.M. Filitov, F.I. Novik, B.M. Tupolev (all from Moscow), A.E. Epifanov (Volgograd), V.S. Pavlov (Nizhnii Novgorod), M.N. Suprun (Arkhangelsk), 
V.L. Chernoperov (Ivanovo), researcher of GIIM, Dr. M. Uhl, Dr. A. Hilger (Hamburg), other authoritative specialists. A 'round table' was arranged on 'German prisoners of war in the USSR'. Head of St Petersburg office of Konrad-AdenauerStiftung, Ms. E. Bauer, an educated historian who took an active part in the seminar, highly appreciated our work. Based on its results, a scientific collection edited by V.B. Konasov and B.V. Petelin was published ${ }^{35}$.

\section{Conclusion}

In October 2009, we held another conference in Vologda in the format of a 'scientific seminar' on the topic: 'Political Turns in Soviet-German History: 1949-1989: Searches. Hope. Accomplishments ${ }^{36}$. The participants came from different cities of Russia and the Republic of Belarus. Konrad-Adenauer-Stiftung (St Petersburg) traditionally rendered its assistance in carrying out our endeavours. Viktor Borisovich Konasov was no longer among us. A year ago, on $28^{\text {th }}$ June 2008, he died suddenly. However his scientific endeavors, developments and research were continued by his students. His name has not been forgotten either. The well-known Vologda journalist Gennadii Akinkhov wrote about Viktor Borisovich in his book 'Breakthrough': "And our Konasov from Vologda, having discovered for himself such a topic of scientific research, which only a few historians of the Soviet Union had dared to take, managed to develop it in such a way that this work became a genuine breakthrough in one of the directions of historical science, both in Russia and abroad"37.

Another important thing for us is that created in 1998 with the participation of V.B. Konasov Museum of Military Glory Club 'Scarlet Sails' in Vologda continues its activities. On $25^{\text {th }}$ May 2018, within the walls of the museum, the first city military-patriotic conference took place in memory of the Vologda scientist - historian Viktor Borisovich Konasov ${ }^{38}$. Such an example is not unique in the social and scientific life of Vologda, and not only there.

\section{Список литературы}

Акиньхов Г.А. Прорыв. Из жизни ученых. Вологда: Полиграфист, 2008. 143 с.

Визит Канцлера Аденауэра в Москву 8-14 сентября 1955 г. Документы и материалы. М.: Права человека, 2005. 232 с.

${ }^{35}$ Establishment of diplomatic relations between the USSR and the FRG. German prisoners of war in the USSR: Materials of the International Scientific Seminar (Vologda, 17-18 ${ }^{\text {th }}$ October 2005) (Vologda, 2006).

${ }^{36}$ Political Turns in Soviet-German History: 1949-1989: Searches. Hope. Accomplishments: Materials of the international scientific seminar (Vologda, 6-7 $7^{\text {th }}$ October 2009), ed. B.V. Petelin; compiled by E. Bauer, B.V. Petelin (Vologda: Graffiti, 2010).

37 See: G. Akin'khov, Breakthrough. From the lives of scientists (Vologda: Human Rights, 2008).

${ }^{38}$ http: dtdm.edu.ru/музей-воинской-славы-алые-паруса-му/ 
Германия и Россия в XX веке: две тоталитарные диктатуры, два пути к демократии: Материалы международной научной конференции (г. Кемерово, 19-22 сентября 2000 г.). Серия: «Германские исследования в Сибири». Кемерово: Западно-Сибирский центр германских исследований, 2001. 500 с.

Духовность как основа общения. Материалы научно-практической конференции. Вологда, 2002. 281 с.

Историк и его время. Памяти профессора В.Б. Конасова: Сборник статей / под ред. В.В. Попова; сост. А.Л. Кузьминых. Вологда: Граффити, 2010. 532 с.

Историк о судьбах немецких военнопленных в СССР: [рецензии и отзывы на книги В.Б. Конасова]. М.: Институт военной истории Министерства обороны Российской Федерации, 1997. $50 \mathrm{c}$.

За Германию - против Гитлера! Документы и материалы о создании и деятельности Национального комитета «Свободная Германия» и Союза немецких офицеров. Мемориальный музей немецких антифашистов. Красногорск: Мемориальный музей немецких антифашистов, 1993. 512 с.

Конасов В.Б. Гриф секретности снят: (к истории немецких военнопленных в СССР). Вологод. гос. пед. ин-т, Группа «Поиск». Вологда: Вологодский государственный педагогический институт, 1991. 55 с.

Конасов В.Б. Судьбы немецких военнопленных в СССР: дипломатические, правовые и политические аспекты проблемы. Очерки и документы. Вологда: Институт повышения квалификации и переподготовки кадров, 1996. 320 с.

Конасов В.Б. «Узники войны»: попытки решения проблемы на дипломатическом Уровне // Трагедия плена: Сборник материалов Международной научно-практической конференции «Окончание войны, завершение деятельности НКСГ/СНО и начало репатриации военнопленных». Москва-Красногорск 31 октября - 2 ноября 1995 г. (Серия С-П). Красногорск: Мемориальный музей немецких антифашистов, 1996. С. 138-141.

Конасов В.Б., Петелин Б.В. Роль Швеции в облегчении участи советских военнопленных в годы второй мировой войны // Европейский Север в культурно-историческом процессе. К 625-летию города Кирова: Материалы международной конференции. Администрация Кировской области. Киров: Кировский областной краеведческий музей. Шведский культурный центр, 1999. С. 138-141.

Конасов В.Б., Петелин Б.В. Сопротивление и плен: документы и материалы по истории антифашистского движения Сопротивления и военного плена в Германии и СССР. 19331955 гг. Ч. 1. Вологда: Институт повышения квалификации и переподготовки кадров, 2000. $136 \mathrm{c}$.

Конасов В.Б. Проблема немецких военнопленных в свете современных российскогерманских отношений // Вехи российско-германских отношений (40-90-е годы XX века): материалы Междунар. науч. конф., г. Волгоград, 24-27 мая 2001. Волгоград: Волгоградский государственный университет, 2001. С. 127-132.

Образцова Е.В. Ресоциализация немецких военнопленных после возвращения из СССР (1945-1955): автореф. дис. ... канд. ист. наук. Воронеж, 2017. 28 с.

Петелин Б.В. Деятельность Национального комитета «Свободная Германия» в исторических трудах А.С. Бланка // Сборник материалов российско-германской научно-практической конференции. Москва - Красногорск 7-9 сентября 1993 г. (серия С-1). Красногорск, 1994. C. $123-129$.

Петелин Б.В. Плен и политика: ХДС/ХСС и проблема немецких военнопленных в 19451955 гг. // Проблемы военного плена: история и современность: Материалы Международ- 
ной научно-практической конференции 23-25 октября 1997 г. Вологда, Ч. 2. Вологда: Вологодский институт повышения квалификации и переподготовки кадров, 1997. С. 148-152.

Петелин Б.В. Историческая германистика в Вологде: предварительные итоги // Новейшая история Германии. Труды молодых ученых и исследовательские центры. М.: КДУ, 2007. C. 357-365.

Петелин Б.В. Вологда в жизни и научной деятельности Александра Ивановича Борозняка // Преодоление прошлого в Германии и России: опыт и уроки на будущее (памяти профессора А.И. Борозняка): материалы Международной научной конференции (1617 февраля 2017. г. Липецк). Липецк: ЛГПУ имени П.П. Семенова-Тян-Шанского, 2017. C. 23-30.

Политические повороты в советско-германской истории: 1949-1989: Поиски. Надежды. Свершения: Материалы международного научного семинара (Вологда, 6-7 октября 2009 г.) / отв. ред. Б.В. Петелин; сост. Э. Бауэр, Б.В. Петелин. Вологда: Граффити, 2010. 258 с.

Разрушение и возрождение в истории Германии и России: Сборник статей международной научной конференции (г. Томск, 23-25 сентября 2009 г.); Серия: «Германские исследования в Сибири». Вып. 7. Томск: Томский университет, 2010. 550 с.

Установление дипломатических отношений между СССР и ФРГ. Немецкие военнопленные в СССР: Материалы Международного научного семинара (Вологда, 17-18 октября 2005 г.). Вологда, 2006. 98 с.

Blank A. Die deutschen Kriegsgefangenen in der UdSSR. Pahl-Rugenstein Verlag. Köln: PahlRugenstein Verlag, 1979. 208 S.

Die Protokolle des CDU-Bundesvorstands 1953-1957. Düsseldorf: Droste Verlag, 1990. $1380 \mathrm{~S}$.

\section{References}

Akin'khov, G.A. Proryv. Iz zhizni uchenykh [Breakthrough. From the Life of Scientists]. Vologda: Poligrafist, 2008. (In Russian)

Blank, A. Die deutschen Kriegsgefangenen in der UdSSR. Pahl-Rugenstein Verlag. Köln: Pahl-Rugenstein Verlag, 1979. (In German)

Die Protokolle des CDU-Bundesvorstands 1953-1957. Düsseldorf: Droste Verlag, 1990. (In German)

Dukhovnost' kak osnova obshcheniya. Materialy nauchno-prakticheskoi konferentsii [Spirituality as the basis of communication. Materials of the scientific-practical conference]. Vologda, 2002. (In Russian)

Germaniya i Rossiya v 20 veke: dve totalitarnye diktatury, dva puti k demokratii: Materialy mezhdunarodnoi nauchnoi konferentsii (g. Kemerovo, 19-22 sentyabrya 2000 g.). Seriya: "Germanskie issledovaniya $v$ Sibiri" [Germany and Russia in the $20^{\text {th }}$ century: Two totalitarian dictatorships, two ways to democracy: Proceedings of the international scientific conference (Kemerovo, 19-22 ${ }^{\text {nd }}$ September). Series: 'German Studies in Siberia']. Kemerovo: Zapadno-Sibirskii tsentr germanskikh issledovanii, 2001. (In Russian)

Istorik i ego vremya. Pamyati professora V.B. Konasova: Sbornik statei; pod red. V.V. Popova; sost. A.L. Kuz'minykh [The historian and his time. In memory of Professor V.B. Konasov: Collection of articles], ed. A.L. Kuz'minykh. Vologda: Graffiti, 2010. (In Russian)

Istorik o sud'bakh nemetskikh voennoplennykh $v$ SSSR: retsenzii $i$ otzyvy na knigi V.B. Konasova [The historian about the fate of German prisoners of war in the USSR: reviews and opin- 
ions on the books of V.B. Konasov]. Moscow: Institut voennoi istorii Ministerstva oborony Rossiiskoi Federatsii, 1997. (In Russian)

Konasov, V.B. Grif sekretnosti snyat: (k istorii nemetskikh voennoplennykh v SSSR) [Declassified: (to the history of German prisoners of war in the USSR)]. Vologda: Vologodskii gosudarstvennyi pedagogicheskii institut, 1991. (In Russian)

Konasov, V.B. Sud'by nemetskikh voennoplennykh v SSSR: diplomaticheskie, pravovye $i$ politicheskie aspekty problemy. Ocherki $i$ dokumenty [The fate of German prisoners of war in the USSR: diplomatic, legal and political aspects of the problem. Essays and documents]. Vologda: Institut povysheniya kvalifikatsii i perepodgotovki kadrov, 1996. (In Russian)

Konasov, V.B. “' 'Uzniki voiny': popytki resheniya problemy na diplomaticheskom Urovne” ['Prisoners of War': attempts to solve the problem at the diplomatic level]. In Tragediya plena: Sbornik materialov Mezhdunarodnoi nauchno-prakticheskoi konferentsii "Okonchanie voiny, zavershenie deyatel'nosti NKSG/SNO $i$ nachalo repatriatsii voennoplennykh” (MoskvaKrasnogorsk 31 oktyabrya - 2 noyabrya 1995 g. (Seriya S-P)) [The Tragedy of Captivity: A collection of materials of the international scientific and practical conference 'End of the war, the completion of the activities of the NCSG / SSS and the beginning of the repatriation of prisoners of war' (Moscow - Krasnogorsk $31^{\text {st }}$ October $-2^{\text {nd }}$ November 1995)], 138-141. Krasnogorsk: Memorial'nyi muzei nemetskikh antifashistov, 1996. (In Russian)

Konasov, V.B., and B.V. Petelin. "Rol' Shvetsii v oblegchenii uchasti sovetskikh voennoplennykh v gody vtoroi mirovoi voiny" [The role of Sweden in facilitating the fate of Soviet prisoners of war during World War II]. In Evropeiskii Sever v kul'turno-istoricheskom protsesse. $K$ 625-letiyu goroda Kirova: Materialy mezhdunarodnoi konferentsii. Administratsiya Kirovskoi oblasti [The European North in the cultural and historical process. To the $625^{\text {th }}$ anniversary of the city of Kirov: Materials of the international conference. Administration of the Kirov region], 138141. Kirov: Kirovskii oblastnoi kraevedcheskii muzei. Shvedskii kul'turnyi tsentr, 1999. (In Russian)

Konasov, V.B., and B.V. Petelin. "Soprotivlenie i plen: dokumenty i materialy po istorii antifashistskogo dvizheniya Soprotivleniya i voennogo plena v Germanii i SSSR. 1933-1955 gg." Ch. 1 [Resistance and captivity: documents and materials on the history of the anti-fascist movement of the Resistance and military captivity in Germany and the USSR. 1933-1955, vol. 1]. Vologda: Institut povysheniya kvalifikatsii i perepodgotovki kadrov, 2000. (In Russian)

Konasov, V.B. "Problema nemetskikh voennoplennykh $\mathrm{v}$ svete sovremennykh rossiiskogermanskikh otnoshenii" [Problem of the German prisoners of war in the light of the modern Russian-German relations]. In Vekhi rossiisko-germanskikh otnoshenii (40-90-e gody XX veka): Materialy Mezhdunar. nauch. konf., g. Volgograd, 24-27 maya 200 [Milestones of Russian-German relations (1940-90s): Materials of international scientific conference, Volgograd, 24-27 ${ }^{\text {th }}$ May 2001], 127-133. Volgograd: Volgogradskii gosudarstvennyi universitet, 2001. (In Russian)

Obraztsova, E.V. "The resocialization of German prisoners of war after their return from the USSR (1945-1955)", PhD thesis. Voronezh, 2017. (In Russian)

Petelin, B.V. 'Deyatel'nost' Natsional'nogo komiteta 'Svobodnaya Germaniya' v istoricheskikh trudakh A.S. Blanka" [The activities of the National Committee for a Free Germany in the historical works of A.S. Blank]. In Sbornik materialov rossiisko-germanskoi nauchno-prakticheskoi konferentsii. Moskva - Krasnogorsk 7-9 sentyabrya 1993 g. (seriya S-1) [Collection of materials of the Russian-German scientific-practical conference (Moscow - Krasnogorsk $7-9^{\text {th }}$ September 1993)], 123-129. Krasnogorsk, 1994. (In Russian)

Petelin, B.V. "Istoricheskaya germanistika v Vologde: predvaritel'nye itogi" [Historical Germanic studies in Vologda: Preliminary results]. In Noveishaya istoriya Germanii. Trudy molodykh 
uchenykh i issledovatel'skie tsentry [The newest history of Germany. Proceedings of young scientists and research centers], 357-365. Moscow: KDU, 2007. (In Russian)

Petelin, B.V. "Plen i politika: KhDS/KhSS i problema nemetskikh voennoplennykh v 19451955 gg." [Captivity and politics: CDU / CSU and the problem of German prisoners of war in 1945-1955]. In Problemy voennogo plena: istoriya i sovremennost': Materialy Mezhdunarodnoi nauchno-prakticheskoi konferentsii (Vologda, 23-25 oktyabrya 1997 g.), ch. 2 [Problems of military captivity: History and modernity: Proceedings of the international scientific and practical conference (Vologda, 23-25 ${ }^{\text {th }}$ October 1997), vol. 2], 148-152. Vologda: Vologodskii institut povysheniya kvalifikatsii i perepodgotovki kadrov, 1997. (In Russian)

Petelin, B.V. "Vologda v zhizni i nauchnoi deyatel'nosti Aleksandra Ivanovicha Boroznyaka" [Vologda in the life and scientific work of Alexander Ivanovich Boroznyak]. In Preodolenie proshlogo v Germanii i Rossii: opyt i uroki na budushchee (pamyati professora A.I. Boroznyaka): materialy Mezhdunarodnoi nauchnoi konferentsii (Lipetsk, 16-17 fevralya 2017. g.) [Overcoming the past in Germany and Russia: Experience and lessons for the future (in memory of Professor A.I. Boroznyak): Materials of the international scientific conference (Lipetsk, 16-17 $7^{\text {th }}$ February 2017)], 23-30. Lipetsk: LSPU imeni P.P. Semenova-Tyan-Shanskogo, 2017. (In Russian)

Politicheskie povoroty v sovetsko-germanskoi istorii: 1949-1989: Poiski. Nadezhdy. Sversheniya: Materialy mezhdunarodnogo nauchnogo seminara (Vologda, 6-7 oktyabrya 2009 g.) [Political Turns in Soviet-German History: 1949-1989: Searches. Hope. Accomplishments: Materials of the international scientific seminar (Vologda, 6- $7^{\text {th }}$ October 2009)]; edited by B.V. Petelin; compiled by E. Bauer, B.V. Petelin]. Vologda: Graffiti, 2010. (In Russian)

Razrushenie $i$ vozrozhdenie $v$ istorii Germanii $i$ Rossii: Sbornik statei mezhdunarodnoi nauchnoi konferentsii (g. Tomsk, 23-25 sentyabrya 2009 g.); Seriya: "Germanskie issledovaniya v Sibiri". Vyp. 7 [Destruction and revival in the history of Germany and Russia: Collection of articles of the international scientific conference (Tomsk, 23-25 ${ }^{\text {th }}$ September 2009); Series: 'German Studies in Siberia', iss. 7]. Tomsk: Tomskii universitet, 2010. (In Russian)

Ustanovlenie diplomaticheskikh otnoshenii mezhdu SSSR i FRG. Nemetskie voennoplennye v SSSR: Materialy mezhdunarodnogo nauchnogo seminara (Vologda, 17-18 oktyabrya 2005 g.) [Establishment of diplomatic relations between the USSR and the FRG. German prisoners of war in the USSR: Proceedings of the international scientific seminar (Vologda, 17-18 ${ }^{\text {th }}$ October 2005)]. Vologda, 2006. (In Russian)

Vizit Kantslera Adenauera v Moskvu 8-14 sentyabrya 1955 g. Dokumenty i materialy [Visit of the Chancellor of Adenauer to Moscow on 8-14 ${ }^{\text {th }}$ September 1955 Documents and Materials]. Moscow: Prava cheloveka, 2005. (In Russian)

Za Germaniyu - protiv Gitlera! Dokumenty $i$ materialy o sozdanii $i$ deyatel'nosti Natsional'nogo komiteta "Svobodnaya Germaniya" i Soyuza nemetskikh ofitserov [For Germany against Hitler! Documents and materials on the creation and activities of the National Committee for a Free Germany and the German Officers League]. Krasnogorsk: Memorial Museum of German anti-fascists, 1993. (In Russian) 